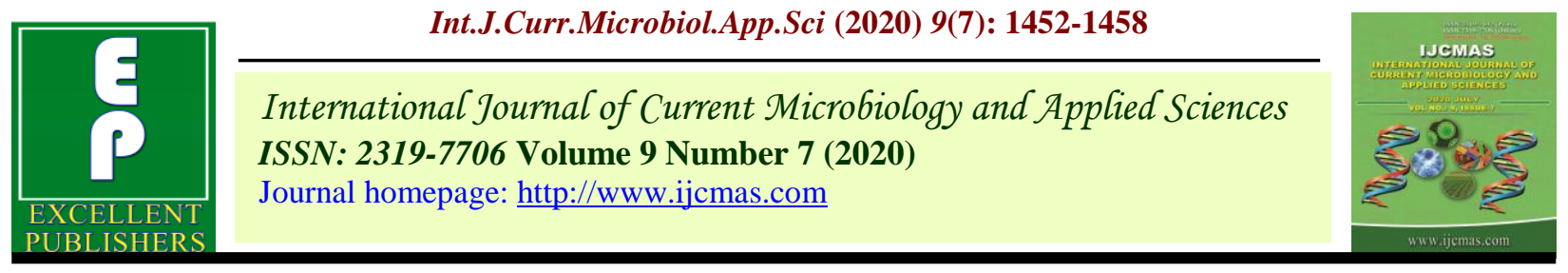

Original Research Article

https://doi.org/10.20546/ijcmas.2020.907.166

\title{
Effect of Pre-harvest Spray on Yield and Quality of Guava (Psidium guajava L.) cv. Allahabad Safeda
}

\author{
M. Qasim ${ }^{1}$, D. Vidhya $^{1 *}$, P. Paramaguru ${ }^{1}$, K.B. Sujatha ${ }^{1}$ and S.K. Manoranjitham ${ }^{1}$ \\ Department of Fruit Science, Horticultural College and Research Institute, Tamilnadu \\ Agricultural University, Coimbatore-3, Tamilnadu, India
}

*Corresponding author

\section{A B S T R A C T}

\section{Keywords}

Guava, Calcium compounds, Salicylic acid

Article Info

Accepted:

14 June 2020 Available Online:

11 July 2020
The effect of pre-harvest spray of salicylic acid, calcium chloride and calcium nitrate on guava (Psidium guajava L.) cv. Allahabad Safeda studied to assess the impact on yield and quality of guava. Pre-harvest spray of calcium chloride 1.5 per cent and 1 per cent enhanced the fruit growth at 15 days after spray (DAS) and at harvest over control. Among the treatments, spraying of calcium chloride @ 1.5 per cent registered the maximum number of fruit per tree (103.33), fruit weight $(162.47 \mathrm{~g})$, fruit volume $(164.47 \mathrm{ml})$, circumference $(21.16 \mathrm{~cm})$, firmness $(1.83 \mathrm{~kg} / \mathrm{cm} 2)$, specific gravity $(0.988 \mathrm{~g} / \mathrm{ml})$, yield $(16.78 \mathrm{~kg} /$ tree $)$, titrable acidity $(0.62$ per cent), ascorbic acid (226.15 mg/g) and shelf life (10.33 days) over control (T7).

\section{Introduction}

Guava (Psidium guajava L.) is an important fruit crop of India. Due to hardy nature of the plant it can withstand adverse climatic conditions and grown under a wide range of soil types from sandy loam to clay loam (Dhaliwal and Singla, 2002). It is normally consumed fresh as a dessert fruit or processed into puree, juice, concentrate, jam, jelly, nectar or syrup (Jagtiani et al., 1988). Guava fruits have high perishability and lose its quality and texture in four to five days at ambient storage. Once the fruit is completely ripe, it becomes soft which reduce marketability and consumer preference rapidly. Application of suitable chemicals as a pre-harvest spray is required to conserve and enhance the fruit yield, quality at harvest as well as post-harvest life of fruits. Primary nutrients such as nitrogen, phosphorus and potassium have a predominant role in the vegetative and reproductive stage of guava along with application of secondary nutrient calcium and plant growth regulators which enhance the fruit growth and quality. Calcium regulates the ripening of fruits because it stimulates fruit colour development, ethylene 
production and enhances flesh firmness (Gerasopoulos and Richardson, 1999). It prevents physiological disorders, reduces the rate of respiration and solubilization of pectic substance (Burns and Pressey, 1987). Salicylic acid acts as a growth regulator, is a natural compound present in the plant system, which plays an important role in many physiological processes. Salicylic acid is accepted as safe and natural chemical compound for pre and post-harvest application on fruits to delay ripening, softening and reduction in lipid peroxidation and chilling injury in fruits (Zhang et al., 2003). Generally, salicylic acid could maintain firmness, reduce the loss of chlorophyll content, alleviate chilling injury, induce pathogenic resistance and improve nutritional value by enhancing bioactive compounds and antioxidants also maintain post-harvest quality, control diseases and alleviate physiological disorders during storage (Asghari et al., 2010). Hence, keeping this in view present investigation was conducted to find out the effect of pre-harvest spray of calcium chloride, calcium nitrate and salicylic acid on growth, yield and postharvest behavior of guava cv. Allahabad Safeda.

\section{Materials and Methods}

A field experiment was conducted at Ayarpadi village, Karamadai, Coimbatore, Tamil Nadu during November 2019 onwards. The experimental plot is located at $11^{\circ} 14^{\prime}$ $29 \mathrm{~N}$ latitude, $76^{\circ} 57^{\prime} 40 \mathrm{E}$ longitude and 353 meter elevation above the mean sea level. The guava variety selected for this study was Allahabad Safeda. The experiment was laid out in Randomized Block Design (RBD) and replicated thrice. The treatments were randomly allotted to different plots using random number table of Fisher and Yates (1963). The treatment details were $\mathrm{T}_{1}$ (Calcium chloride @1per cent), $\mathrm{T}_{2}$ (Calcium chloride@1.5per cent), $\mathrm{T}_{3}$ (Calcium nitrate @ 1per cent), $\mathrm{T}_{4}$ (Calcium nitrate @ 1.5per cent), $\mathrm{T}_{5}$ (Salicylic acid @ 500 $\mu \mathrm{m}$ ), $\mathrm{T}_{6}$

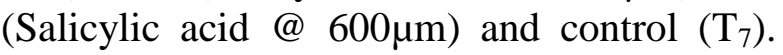
The treatments were imposed at three months after fruit set. The guava fruits were harvested at green mature stage and were used for the analysis at the Department of Fruit Science, TNAU, Coimbatore. Fruit length and diameter were observed by using digital verniar caliper and expressed in centimeter. The firmness of guava fruits was measured by penetrometer (Model: GY- 4, Sundoo industries co., ltd, China). The whole fruit was taken and penetrated with $5 \mathrm{~mm}$ diameter probe. Four observations were taken for each sample (two at lateral and two points on either ends of the fruit). It was measured in term of $\mathrm{kg} / \mathrm{cm}^{2}$. The volume of fruit was measured by dipping fruits in a known volume of water in a graduated cylinder and expressed as $\mathrm{ml}$. The specific gravity of the fruit was measured by water displacement method and values were expressed as $\mathrm{g} / \mathrm{ml}$. Ascorbic acid was estimated by oxalic acid titration method (Harris and Ray, 1935). Titrable acidity was assessed by titrating the sample extracted in water against sodium hydroxide using phenolphthalein as an indicator. The acidity was expressed in terms of percentage (Ranganna, 1977). Total soluble solids were determined at room temperature with the help of hand refractometer (Range: 0 -32; Model ERMA, Japan) and TSS was expressed in term of ${ }^{\circ}$ brix. The sugar - acid ratio was calculated by dividing the total soluble solids by titrable acidity. The shelf life of the fruits was assessed under normal ambient condition.

\section{Results and Discussion}

The fruit length and diameter of guava cv. Allahabad Safeda was influenced significantly from 15 days after spray (DAS) till harvest by the pre-harvest spray of chemicals (Table 1). The maximum fruit 
length $(5.45 \mathrm{~cm}$ and $6.21 \mathrm{~cm})$ and diameter $(5.60 \mathrm{~cm}$ and $6.74 \mathrm{~cm})$ was registered by $\mathrm{T}_{2}$ $\left(\mathrm{CaCl}_{2} @ 1.5\right.$ per cent) respectively at $15 \mathrm{DAS}$ and at harvest. The lowest fruit length (5.15 $\mathrm{cm}$ and $5.94 \mathrm{~cm})$ and diameter $(5.05 \mathrm{~cm}$ and $6.00 \mathrm{~cm}$ ) was recorded by the control $\mathrm{T}_{7}$. Preharvest application of calcium and salicylic acid significantly increased the fruit growth, yield and yield attributes in guava cv. Allahabad Safeda over control (Table $1 \& 2$ ). The number of fruit/tree (103.33), fruit weight $(162.47 \mathrm{~g})$, fruit volume $(164.47 \mathrm{ml})$, fruit circumference $(21.16 \mathrm{~cm})$ fruit specific gravity $(0.988 \mathrm{~g} / \mathrm{ml})$, fruit firmness (1.83 $\left.\mathrm{kg} / \mathrm{cm}^{2}\right)$ and yield (16.78 $\mathrm{kg} /$ tree $)$ was maximum for the treatment $\mathrm{T}_{2}$ which received pre-harvest spray of 1.5 per cent calcium chloride followed by $T_{1}$. The lowest number of fruit/tree (93.33), fruit weight (138.87 g), fruit volume $(142.32 \mathrm{ml})$, fruit circumference $(18.68 \mathrm{~cm})$, fruit firmness $\left(1.49 \mathrm{~kg} / \mathrm{cm}^{2}\right)$ and yield $(12.93 \mathrm{~kg} /$ tree) was observed in control $\left(\mathrm{T}_{7}\right)$. Among the nutrients spray next to calcium chloride, application of salicylic acid recorded the maximum values for the yield and yield attributes.

The growth and yield increment by the treatment $\mathrm{T}_{2}$ may be due to the macronutrient calcium as it can enhance the length, diameter, weight, circumference, volume and specific gravity of guava fruits. This might be due to role of calcium in enhancing cell division, promoting the root growth resulting in increased nutrient absorption (Sathya et al., 2010). Calcium also increased the number of fruits by reducing fruit drops. Bokkisam, (2007) reported the role of calcium in enhancing meristem growth, cell elongation and nutrient uptake. Calcium activates many enzymes in plant systems like phospholipase, arginine kinase, amylase and adenosine tri phosphatase (ATP ase). All these factors might contribute to increased uptake and utilization of nutrients from soil thus increasing the photosynthetic activity. The increased photosynthesis might have helped in better vegetative growth and photosynthate accumulation resulting in increased weight of the fruit (Tejashvini et al., 2018). The beneficial effects of calcium applications on fruit firmness could be attributed to the binding role of calcium with the complex polysaccharides and proteins involved in the formation the cell wall (Tuckey, 1983).The present study corroborate with finding of Ola, (2018) where the pre-harvest spray of calcium increased the firmness of guava fruits.

Application of calcium chloride increased the guava yield that might be due to the increase in the number of fruits/tree, reduced abscission and increased fruit growth and yield attributes. Similar results have been reported by Kher et al., (2005) which connote that pre - harvest application of calcium chloride increased the yield of guava fruits. Fruit quality attributes were also significantly influenced by pre-harvest application of chemicals (Table 3). Treatments which received calcium compounds and salicylic acid registered lowest TSS over control (10.45 brix) at the time of harvest. Application of calcium might decrease the total soluble solid of guava cv. Allahabad Safeda due to the role of calcium chloride in delaying the ripening of fruits by inhibiting of ethylene production (Singh et al., 1998). Calcium chloride can also suppress respiration rate, slows down the synthesis and the use of metabolites, resulting in reduction of TSS by slow down hydrolysis of carbohydrates to sugars (Das et al., 2013). The present findings are supported by the studies of Wahdan et al., (2011). The highest acidity (0.62 per cent) was recorded in $\mathrm{T}_{2}$ which received calcium chloride @ 1.5 per cent followed by $\mathrm{T}_{1}(0.59$ per cent $)$ and the lowest acidity recorded in control (0.49 per cent). Calcium chloride increased the titrable acidity of guava fruits as calcium delayed the ripening by decreased hydrolysis of organic 
acids and respiration rate (Gupta et al., 2011). The highest titrable acidity in guava cv. Allahabad Safeda for calcium chloride $\left(\mathrm{T}_{2}\right)$ spray was in line with the studies of Padmavathi (1999) where calcium application increased titrable acidity in banana. Similar findings were observed by Swosti and Sanjay, (2015) where pre - harvest application of calcium chloride maintained high titrable acidity in guava fruits cv. L- 49.

Among the treatments, ascorbic acid content in the fruit significantly differed from 226.15 $\mathrm{mg} / 100 \mathrm{~g}\left(\mathrm{~T}_{2}\right)$ to $198.63 \mathrm{mg} / 100 \mathrm{~g}\left(\mathrm{~T}_{7}\right)$. The maximum ascorbic acid was recorded in $T_{2}$ followed by $T_{1}$ and the minimum was recorded in control. Pre-harvest spray of calcium increased ascorbic acid of guava fruits. This might be due to synthesis of some metabolites and intermediate substances which promote the synthesis of precursor of ascorbic acid resulted in increased levels of ascorbic acid (Bhat et al., 2009). Also calcium chloride retarded oxidation process and increases the rate of conversion of Lascorbic acid to de-hydro ascorbic acid (Singh et al., 1982). Sugar: acid ratio in control is (21.35) followed by $\mathrm{T}_{3}(20.64)$ and the lowest value were recorded in $\mathrm{T}_{2}$ (16.21). The least sugar: acid ratio was observed in the treatment that received calcium chloride and salicylic acid. Spraying calcium and salicylic acid might be reduced the polysaccharides conversion to simple sugars by delaying the ripening and slows down the respiration rate. The shelf life (10.33 days) of guava fruits by the treatment $T_{2}$ was significantly more and was on par with $\mathrm{T}_{1}$ and it was least (6.00 days) in control, which indicate that calcium chloride spray can extend the shelf life of guava fruit by maintaining fruit firmness, reducing respiration rate, proteolysis and tissue breakdown. It also acts as an antisenescence agent by preventing cellular disorganization through protein and nucleic acid synthesis (Cheour et al., 1991 and Manmohan et al., 2018).

Table.1 Effect of pre - harvest spray on growth of guava (Psidium guajava L.) cv. Allahabad Safeda at the time of spray, 15 days after spray (DAS) and at harvest

\begin{tabular}{|c|c|c|c|c|c|c|}
\hline \multirow[t]{2}{*}{ Treatments } & \multicolumn{3}{|c|}{ Fruit length $(\mathrm{cm})$} & \multicolumn{3}{|c|}{ Fruit diameter $(\mathrm{cm})$} \\
\hline & at spray & 15 DAS & at harvest & at spray & 15 DAS & at harvest \\
\hline $\mathrm{T}_{1}-\left(\mathrm{CaCl}_{2} @ \mathbf{1 \%}\right)$ & 4.34 & 5.40 & 6.17 & 3.48 & 5.55 & 6.69 \\
\hline $\mathbf{T}_{2}-\left(\mathrm{CaCl}_{2} @ 1.5 \%\right)$ & 4.39 & 5.45 & 6.21 & 3.53 & 5.60 & 6.74 \\
\hline $\mathrm{T}_{3}-\left(\mathrm{Ca}\left(\mathrm{NO}_{3}\right)_{2} @ 1 \%\right)$ & 4.23 & 5.30 & 6.03 & 3.36 & 5.40 & 6.36 \\
\hline $\mathrm{T}_{4}-\left(\mathrm{Ca}\left(\mathrm{NO}_{3}\right)_{2} @ 1.5 \%\right)$ & 4.28 & 5.33 & 6.07 & 3.38 & 5.44 & 6.40 \\
\hline $\mathbf{T}_{5}-($ Salicylic acid @ 500 $\mu \mathrm{m})$ & 4.31 & 5.34 & 6.10 & 3.42 & 5.46 & 6.59 \\
\hline 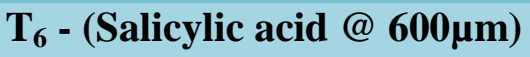 & 4.32 & 5.39 & 6.16 & 3.44 & 5.49 & 6.65 \\
\hline $\mathbf{T}_{7}-($ Control $)$ & 4.06 & 5.15 & 5.94 & 3.10 & 5.05 & 6.00 \\
\hline Mean & 4.28 & 5.34 & 6.09 & 3.39 & 5.43 & 6.49 \\
\hline SED & 0.159 & 0.058 & 0.048 & 0.278 & 0.026 & 0.024 \\
\hline $\mathrm{CD}(0.05)$ & NS & $0.128 * *$ & $0.106 * *$ & NS & $0.079 * *$ & $0.074 * *$ \\
\hline
\end{tabular}


Table.2 Effect of pre - harvest spray on yield and yield attributes of guava (Psidium guajava L.) cv. Allahabad Safeda

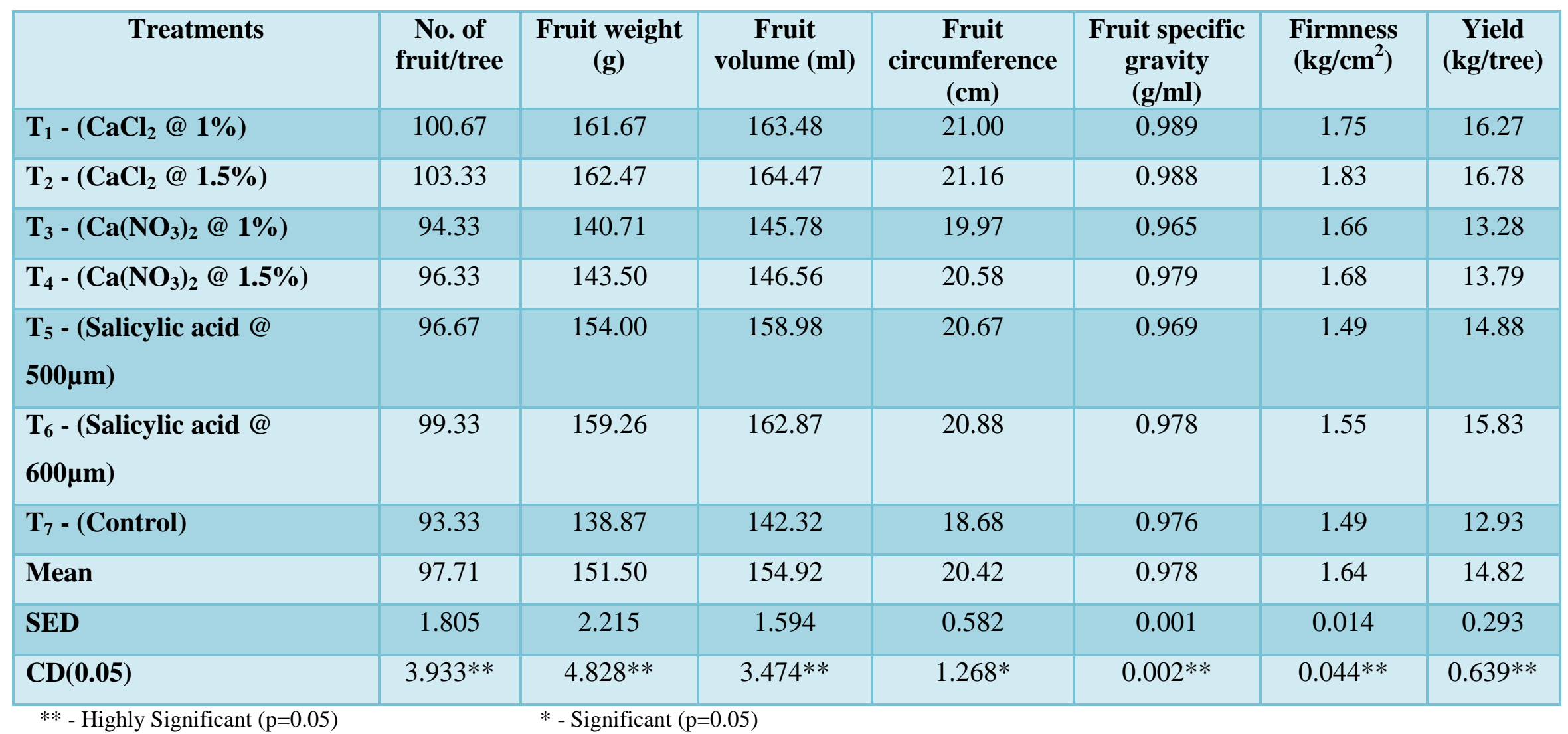


Table.3 Effect of pre - harvest spray on quality attributes of guava (Psidium guajava L.) cv. Allahabad Safeda at harvest

\begin{tabular}{|c|c|c|c|c|c|}
\hline Treatments & TSS ( ${ }^{0}$ Brix) & $\begin{array}{c}\text { Titrable } \\
\text { acidity }(\%)\end{array}$ & $\begin{array}{c}\text { Ascorbic acid } \\
(\mathrm{mg} / \mathbf{1 0 0 g})\end{array}$ & $\begin{array}{l}\text { TSS: Acid } \\
\text { ratio }\end{array}$ & $\begin{array}{c}\text { Shelf life } \\
\text { (Days) }\end{array}$ \\
\hline $\mathrm{T}_{1}-\left(\mathrm{CaCl}_{2} @ 1 \%\right)$ & 10.23 & 0.59 & 223.91 & 17.34 & 9.69 \\
\hline $\mathrm{T}_{2}-\left(\mathrm{CaCl}_{2} @ 1.5 \%\right)$ & 10.05 & 0.62 & 226.15 & 16.21 & 10.33 \\
\hline $\mathrm{T}_{3}-\left(\mathrm{Ca}\left(\mathrm{NO}_{3}\right)_{2} @ 1 \%\right)$ & 10.32 & 0.50 & 213.92 & 20.64 & 8.00 \\
\hline $\mathrm{T}_{4}-\left(\mathrm{Ca}\left(\mathrm{NO}_{3}\right)_{2} @ 1.5 \%\right)$ & 10.39 & 0.54 & 218.55 & 19.24 & 9.33 \\
\hline $\mathrm{T}_{5}-($ Salicylic acid @ 500 $\mu \mathrm{m})$ & 10.18 & 0.54 & 220.89 & 18.85 & 9.66 \\
\hline 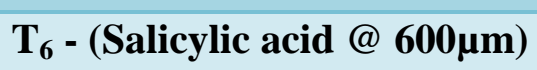 & 10.29 & 0.57 & 221.77 & 18.05 & 9.68 \\
\hline $\mathbf{T}_{7}-($ Control $)$ & 10.45 & 0.49 & 198.63 & 21.35 & 6.00 \\
\hline Mean & 10.27 & 0.55 & 217.69 & 18.81 & 8.96 \\
\hline SED & 0.023 & 0.013 & 0.839 & 0.016 & 0.039 \\
\hline $\mathrm{CD}(\mathbf{0 . 0 5})$ & $0.051^{* *}$ & $0.029 * *$ & $1.829 * *$ & $0.035^{* *}$ & $0.086 * *$ \\
\hline
\end{tabular}

In conclusion, the present investigation implies that pre - harvest application of calcium chloride at 1.5 per cent produced more number of fruit per tree (103.33), increased fruit weight $(162.47 \mathrm{~g})$, fruit volume (164.47 $\mathrm{ml})$, circumference (21.16 $\mathrm{cm})$, firmness $\left(1.83 \mathrm{~kg} / \mathrm{cm}^{2}\right)$, specific gravity $(0.988 \mathrm{~g} / \mathrm{ml})$, yield $(16.78 \mathrm{~kg} /$ tree $)$, titrable acidity ( 0.62 per cent), ascorbic acid (226.15 $\mathrm{mg} / \mathrm{g}$ ) and shelf life (10.33 days) over control. Compare to other treatments, by enhancing the vegetative growth and translocation and accumulating of photosynthates. On the other hand, the TSS was lower in the calcium chloride treated plants (10.05 and 10.23 brix) compared to other treatments and recorded highest (10.45 brix) in control plants which clearly explains the role of calcium in slow conversion of carbohydrates to sugars thereby enhancing the shelf life of the fruits.

\section{Acknowledgement}

The authors would like to give their sincere thanks to Tamil Nadu Agricultural University,
Coimbatore - 3, Tamil Nadu, India for the professional and financial support in the research.

\section{References}

Asghari, Mohammadreza. A, Morteza S., 2010. Impact of salicylic acid on postharvest physiology of Horticultural crops. Trends in Food Science and Technology., 21: 502509.

Bhat, M.Y., Hafiza. A, Banday. F.A, Dar. M.A, Wani. A.I, Hassan. G.I and Khajwall. M.H., 2009. Effect of harvest dates, pre harvest calcium sprays and storage period on physico-chemical characteristics of pear $\mathrm{cv}$. Bartlett., Appl. Biol. Sci. Res., 11(1): 3135.

Bokkisam, H.B., 2007. Effect of $\mathrm{N}$ and $\mathrm{K}$ ratios on yield and quality of chilli on vertisol in northern transitional zone of Karnataka. A Thesis submitted to the Uni. Agri. Sci. Dharwad, Ind.

Burdon, J. N., Moore. K. G, Wainwright. H. A., 1992. Preliminary examination of the physiological disorder "softnose" in mango 
fruits. Acta Horticulture., 296:15-22.

Burns, J. K and R. Pressey., 1987. Calcium in the cell wall of ripening tomato and peach. $\mathrm{J}$. Am. Soc. Hort. Sci., 112: 783-787.

Cheour, F., Willemot. C. J, Arul. Y., Makhlouf. P.M and Desjardins. Y., 1991. Post-harvest response of two strawberry cultivars to foliar application of $\mathrm{CaCl}_{2}$. Hort. Sci., 26: 1186-1188.

Das, D. K., Dutta. H, Mahanta. C. L., 2013. Development of a rice starch-based coating with antioxidant and microbe-barrier properties and study of its effect on tomatoes stored at room temperature. Journal of Food Science and Technology., 50: 272-278.

Dhaliwal, G. S., Singla. R., 2002. Studies on the time of anthesis and dehiscence in different genotypes of guava in winter and rainy season crops. Indian J Hort., 59:157-161

Gerasopoulos, D. and D.G. Richardson., 1999. Storage temperature and fruit calcium alter the sequence of ripening events of "de' Anjou" pears. HortScience., 34(2):316-318.

Gupta, N., S. K. Jawandha and S. P. Gill., 2011. Effect of calcium on cold storage and post cold storage quality of peach. J. Food Sci. Technol., 48(2): 225-229.

Jagtiani, J., Chan. H.T. J and Sakai. W.S., 1988. Tropical fruit processing. Academic Press Inc., New York., pp 9-43.

Kher, R., Bhat, S. and Wali, V. K., 2005. Effect Effect of foliar application of GA3, NAA and CCC on physico-chemical characteristics of guava cv. Sardar. Haryana J. Hort. Sci., 34(1-2): 31-32.

Manmohan, S.B., B.P Bisen and SK Pandey., 2018. Effect of post-harvest treatments on shelf life and quality of Guava (Psidiun guavajava) fruits. International journal of chemical studies., 6(4): 2559-2564.

Ola, M. F., 2018. Effect of edible coating chitosan and calcium gluconate on maintaining fruit quality and marketability of Guava (Psidium guajava L.) fruits during storage. Middle East Journal of Applied Sciences., 8(4): 1046-1060.

Padmavathi., 1999. Post- harvest storage Studies in banana cv. Dwarf Cavendish (Musa AAA). M.Sc. Thesis, Acharya N.G. Ranga Agricultural University, Hyderabad.

Sathya, S., Mani. S, Mahedran. P. P, Arulmozhiselvan. K., 2010. Effect of application of boron on growth, quality and fruit yield of PKM1 tomato. Indian Journal of Agricultural Research., 44: 274-280.

Singh, B.P., Gupta. O.P. and Chauhan. K.S., 1982. Effect of Pre-harvest calcium nitrate spray on peach on the storage life of fruits. Indian J. Agric. Sci., 54: 235-239.

Singh, S., Brahmachari. V.S. and Jha. K.K., 1998. Effect of calcium and polythene wrapping on storage life of mango. Indain J. Hort., 55 (3): 218-222.

Swosti, B. D and S. pathak., 2015. Pre- harvest treatments for fruit quality improvement in rainy season guava $\mathrm{Cv}$. L- 49. IJSR., 6: 7896.

Tejashvini, A., Thippeshappa. G. N. and Adivappar. N., 2018. Growth and Yield Attributes as Influenced by Calcium Foliar Nutrition under Polyhouse Condition, Int. J. Pure App. Biosci., 6(6): 952-957.

Tuckey, R. B., 1983. Calcium spray for sweet cherries. Proceedings of Washington State Horticulture Association., 79:194-198.

Wahdan, M. T., S. E. Habib, M. A. Bassal, and E. M .Qaoud., 2011. Effect of some chemicals on growth, fruiting, yield and fruit quality of "Succary Abiad" mango. Journal of Horticulture Science., 7(2): 651-658.

Zhang, Y., Chen. K.S, Zhang. S.L and Ferguson I., 2003. The role of salicylic acid in post harvest ripening of kiwifruit. Postharvest Biology and Technology, 28:67-74.

\section{How to cite this article:}

Qasim, M., D. Vidhya, P. Paramaguru, K.B. Sujatha and Manoranjitham, S.K. 2020. Effect of Pre-harvest Spray on Yield and Quality of Guava (Psidium guajava L.) cv. Allahabad Safeda. Int.J.Curr.Microbiol.App.Sci. 9(07): 1452-1458. doi: https://doi.org/10.20546/ijcmas.2020.907.166 